\title{
PENGARUH MODEL PEMBELAJARAN KOOPERATIF TIPE STAD TERHADAP HASIL BELAJAR FISIKA SISWA PADA MATERI POKOK GERAK LURUS DI KELAS X SMA SWASTA UISU MEDAN
}

\author{
Asneli Lubis \\ Jurusan Pendidikan Fisika Universitas Negeri Medan
}

\begin{abstract}
Abstrak. Penelitian ini bertujuan untuk mengetahui pengaruh model pembelajaran kooperatif tipe STAD terhadap hasil belajar Fisika siswa pada materi pokok gerak lurus di kelas X SMA SWASTA UISU Medan T.P 2010/2011. Jenis penelitian ini adalah quasi eksperimen dengan populasi seluruh siswa kelas X semester I SMA Swasta UISU yang terdiri dari 4 kelas. Sampel penelitian diambil 2 kelas yang ditentukan dengan teknik cluster random sampling, yaitu Kelas X-3 sebagai kelas eksperimen dengan menggunakan model pembelajaran kooperatif tipe STAD dan kelas X-1 sebagai kelas kontrol dengan menggunakan model pembelajaran konvensional. Berdasarkan hasil uji hipotesis menggunakan uji t diperoleh $t_{\text {hitung }}=3,138>t_{\text {tabel }}=1,667$ sehingga diperoleh kesimpulan ada pengaruh yang signifikan pada penggunaan model pembelajaran kooperatif tipe STAD terhadap hasil belajar siswa pada materi pokok gerak lurus di kelas X SMA Swasta UISU.
\end{abstract}

Kata kunci: model pembelajaran kooperatif, STAD, hasil belajar

\section{Pendahuluan}

Kegiatan proses belajar mengajar di sekolah merupakan usaha dalam meningkatkan kualitas pendidikan nasional, karena sekolah merupakan salah satu perangkat pendidikan. Mengingat Fisika merupakan salah satu mata pelajaran yang penting diberbagai jenjang pendidikan, maka sudah sewajarnya mata pelajaran Fisika dikembangkan dan diperhatikan oleh semua pelaku pendidikan.

Fisika berusaha mengungkapkan rahasia dan hukum semesta yang dapat diterangkan dengan menggunakan konsep yang sederhana. Pada kenyataanya banyak siswa yang kurang tertarik mata pelajaran Fisika, sehingga berpengaruh terhadap hasil belajar yang dicapai oleh siswa. Hal ini dapat dilihat dari nilai mata pelajaran Fisika yang diperoleh siswa lebih rendah dibandingkan dengan nilai yang lain.

Kenyataan tersebut tampak dari hasil observasi yang dilakukan di SMA UISU Medan dengan memberikan angket kepada 35 siswa, sebanyak 17 orang siswa menganggap Fisika itu adalah pelajaran yang sulit dan sebanyak 18 siswa menganggap Fisika merupakan pelajaran yang terlalu banyak rumus dan hapalan. Anggapan sebagian besar siswa yang mengatakan Fisika sebagai pelajaran yang sulit dan membosankan turut mempengaruhi rendahnya pencapaian hasil belajar siwa itu sendiri.

Kenyataan tersebut juga tampak berdasarkan hasil studi pendahuluan yang dilakukan di SMA UISU,diperoleh data hasil belajar Fisika siswa pada ujian tiga semester terakhir yaitu nilai rata-rata siswa 5,$5 ; 5,8 ; 6,1$ sedangkan nilai ketuntasan kompetensi minimal di sekolah tersebut untuk mata pelajaran Fisika adalah 6,0. Sehingga dapat dikatakan pencapaian hasil belajar Fisika masih rendah dan tidak mencapai standar yang diharapkan. Dalam hal ini dapat disimpulkan dahwa di SMA banyak siswa yang mengalami kesulitan belajar. 
Lubis, A.: Pengaruh Model Pembelajaran Kooperatif Tipe STAD Terhadap Hasil Belajar Fisika Siswa Pada Materi Pokok Gerak Lurus di Kelas X SMA Swasta UISU Medan.

Ada beberapa faktor yang dapat mempengaruhi hasil belajar siswa tersebut, antara lain dari pihak pengajar, pihak siswa, sarana dan prasarana serta lingkungan. Dari pihak pengajar salah satunya adalah cara guru yang cenderung lebih menguasai proses pembelajaran dengan menerapkan metode ceramah, metode ini membuat guru mendominasi kegiatan belajar mengajar dikelas sehingga siswa menjadi pasif. Siswa lebih banyak belajar dengan menerima, mencatat dan menghafal pelajaran. Hal inilah yang membuat siswa kurang senang belajar Fisika.

Salah satu alternatif untuk menciptakan kinerja siswa adalah dengan model pembelajaran kooperatif yaitu: model pembelajaran kooperatif tipe STAD. Pembelajaran kooperatif merupakan model pembelajaran atas teori bahwa siswa akan lebih mudah menemukan dan memahami konsep-konsep yang sulit apabila mereka dapat saling mendiskusikan, masalah-masalah dengan temannya, yang menekankan pentingnya kerja sama.

Penelitian mengenai pembelajaran kooperatif tipe STAD sudah pernah diteliti oleh peneliti sebelumnya seperi Gelora (2008). Adapun judul penelitiannya: Pengaruh Model Pembelajaran Kooperatif Tipe STAD Terhadap Hasil Belajar Siswa di SMA Swasta Santo Thomas 3 Pada Materi Pokok Besaran dan Satuan T.P. 2008/2009 diperoleh rata-rata pretes sebesar 76,32 sedangkan pembelajaran konvensional 64,08.

Upaya-upaya yang dilakukan untuk memperbaiki kelemahan-kelemahan tersebut adalah peneliti akan lebih mengoptimalkan alokasi waktu untuk setiap tahap pembelajaran yang sudah ditetapkan dalam Rencana Pelaksanaan pembelajaran, sehingga alokasi waktu untuk setiap tahap pembelajaran efesien.

Berdasarkan latar belakang masalah, maka identifikasi masalahnya adalah (1) Hasil belajar siswa yang kurang memuaskan, (2) Metode pengajaran yang digunakan guru masih bersifat konvensional, (3) Guru masih kurang melibatkan siswa dalam kegiatan belajar mengajar, (4) Interaksi antar siswa dalam
Jurnal Pendidikan Fisika

p-ISSN 2252-732X

e-ISSN2301-7651

kegiatan belajar mengajar masih kurang. Batasan masalahnya mencakup (1) Model pembelajaran yang digunakan adalah pembelajaran Kooperatif Tipe STAD, (2) Subjek penelitian adalah siswa kelas $\mathrm{X}$ semester I SMA Swasta UISU Medan T.P 2010/2011, dan (3) Hasil Belajar siswa dibatasi pada materi pokok gerak lurus.

Berdasarkan batasan masalah di atas, maka rumusan masalah dalam penelitian ini adalah (1) Bagaimanakah hasil belajar siswa yang diberi pengajaran dengan model pembelajaran Kooperatif Tipe STAD pada materi pokok gerak lurus di kelas X semester I SMA swasta UISU Medan T.P 2010/2011? (2) Apakah ada perbedaan pengaruh model pembelajaran Kooperatif Tipe STAD terhadap hasil belajar siswa pada materi pokok gerak lurus di kelas X semester I SMA swasta UISU Medan T.P. 2010/2011? Dari rumusan masalah ini, tujuan penelitiannya adalah untuk (1) mengetahui hasil belajar siswa yang diberi pengajaran dengan model pembelajaran Kooperatif Tipe STAD pada materi pokok gerak lurus di kelas $\mathrm{X}$ semester I SMA swasta UISU Medan T.P 2010/2011, (2) mengetahui ada tidaknya perbedaan pengaruh model pembelajaran Kooperatif Tipe STAD pada materi pokok gerak lurus di kelas X semester I SMA swasta UISU Medan T.P 2010/2011.

\section{Belajar Dan Mengajar}

Setiap orang harus melakukan belajar dengan sungguh-sungguh dalam hidupnya untuk mencapai apa yang dicita-citakan. Menurut Slameto (2003) bahwa belajar adalah suatu proses usaha yang dilakukan seseorang untuk memperoleh suatu perubahan tingkah laku yang baru secara keseluruhan sebagai hasil pengalamannya sendiri dalam interaksi dengan lingkungannya.

Sedangkan menurut Sardiman (2003) bahwa belajar adalah rangkaian kegiatan jiwa raga, psiko-fisik untuk menuju ke perkembangan pribadi manusia seutuhnya yang berarti menyangkut unsur cipta, rasa dan karsa, ranah kognitif, afektif dan psikomotorik. 
Jadi dapat disimpulkan bahwa belajar adalah suatu proses mental yang terjadi dalam diri seseorang dan melibatkan kegiatan berpikir yang terjadi melalui interaksi dengan lingkungan (pengalaman belajar), sehingga terjadi perubahan prilaku yang positif.

\section{Hasil Belajar}

Setiap orang yang melakukan kegiatan belajar pasti ingin mengetahui hasil dari kegiatan belajar yang dilakukan. Siswa dan guru merupakan orang yang terlibat langsung dalam proses pembelajaran. Setelah proses pembelajaran berlangsung, guru selalu mengadakan evaluasi terhadap materi yang telah diajarkan. Hasil evaluasi merupakan hasil belajar siswa dalam proses pembelajaran. Hasil belajar secara umum dipandang sebagai perwujudan nilai-nilai yang diperoleh siswa melalui proses belajar mengajar. Hal ini menunjukkan bahwa hasil belajar adalah penguasaan hubungan-hubungan antara bagian-bagian informasi yang telah diperoleh sehingga siswa dapat menampilkan pengalaman dan penguasaan bahan pelajaran yang dipelajari.

\section{Model Pembelajaran}

Model pembelajaran adalah suatu perencanaan, atau suatu pola yang digunakan sebagai pedoman dalam merencanakan pembelajaran dalam tutorial dan untuk menetukan perangkatperangkat pembelajaran termasuk di dalamnya buku-buku, film, komputer, dan lain-lain (Joyce, 1992). Selanjutnya Joyce menyatakan bahwa setiap model pembelajaran mengarahkan kita ke dalam mendesain pembelajaran untuk membantu peserta didik sedemikian rupa sehingga tujuan pembelajaran tercapai.

Model pembelajaran merupakan bungkus atau bingkai dari penerapan suatu pendekatan, metode, dan teknik pembelajaran. Dengan demikian pemilihan model yang sesuai dapat meningkatkan hasil belajar dan pemahaman siswa terhadap materi, serta guru akan merasakan adanya kemudahan di dalam pelaksanaan pembelajaran di kelas, sehingga tujuan pembelajaran dapat tercapai dan tuntas sesuai dengan yang diharapkan.

\section{Model Pembelajaran Kooperatif}

Pembelajaran kooperatif mengacu pada model pengajaran dimana siswa bekerja sama dalam kelompok kecil saling membantu dalam mempelajari suatu materi pelajaran yang diberikan guru. Pembelajaran kooperatif adalah metode yang spesifik dari collaborative learning, yaitu siswa bekerja bersama-sama, berhadapan muka dalam kelompok kecil dan melakukan tugas yang sudah terstruktur. Lie (2004) mengemukakan bahwa pembelajaran kooperatif adalah suatu sistem pengajaran yang memberi kesempatan kepada anak didik untuk bekerjasama dengan sesama siswa dalam tugastugas yang terstruktur.

Ibrahim, dkk. (2000) mengemukakan ciri-ciri pembelajaran kooperatif yaitu: (1) Siswa bekerjasama dalam kelompok secara kooperatif untuk memutuskan materi belajarnya. (2) Kelompok dibentuk dari siswa yang memiliki kemampuan tinggi, sedang dan rendah. (3) Bila mungkin, anggota kelompok berasal dari ras, budaya, suku, jenis kelamin yang berbeda-beda. (4) Penghargaan lebih berorientasi kelompok daripada individu.

\section{Pembelajaran Kooperatif Tipe STAD}

Pembelajaran kooperatif tipe STAD ini merupakan salah satu tipe dari model pembelajaran kooperatif dengan menggunakan kelompokkelompok kecil dengan jumlah anggota tiap kelompok 4-5 orang siswa secara heterogen. Diawali dengan penyampaian tujuan pembelajaran, penyampaian materi, kegiatan kelompok kuis dan penghargaan kelompok. Slavin (2008) menyatakan bahwa pada STAD siswa ditempatkan dalam tim belajar beranggota 4-5 orang yang merupakan campuran menurut tingkat prestasi, jenis kelamin, dan suku. Guru menyajikan pelajaran, dan kemudian siswa bekerja dalam tim mereka memastikan bahwa seluruh anggota tim telah mengusai pelajaran tersebut. Kemudian, seluruh siswa diberikan tes tentang materi tersebut, pada saat tes ini mereka tidak diperbolehkan saling membantu. 
Langkah-langkah pembelajaran kooperatif tipe STAD ini didasarkan pada langkah-langah kooperatif yang terdiri atas enam langkah atau fase. Fase-fase dalam pembelajaran ini seperti tersajikan dalam tabel.

Tabel 1. Fase-fase pembelajaran kooperatif tipe STAD

\begin{tabular}{|l|l|}
\hline \multicolumn{1}{|c|}{ Fase } & \multicolumn{1}{c|}{ Kegiatan Guru } \\
\hline $\begin{array}{l}\text { Fase 1 } \\
\text { Menyampaikan tujuan dan } \\
\text { memotivasi siswa. }\end{array}$ & $\begin{array}{l}\text { Menyampaikan semua tujuan pelajaran yang ingin dicapai pada } \\
\text { pelajaran tersebut dan memotivasi siswa belajar. }\end{array}$ \\
\hline $\begin{array}{l}\text { Fase 2 } \\
\text { Menyajikan atau menyampaikan } \\
\text { informasi. }\end{array}$ & $\begin{array}{l}\text { Menyajikan informasi kepada siswa dengan jalan } \\
\text { mendemonstrasikan atau lewat bahan bacaan. }\end{array}$ \\
\hline $\begin{array}{l}\text { Fase 3 } \\
\text { Mengorganisasikan siswa dalam } \\
\text { kelompok-kelompok belajar. }\end{array}$ & $\begin{array}{l}\text { Menjelaskan kepada siswa bagaimana caranya membentuk } \\
\text { kelompok belajar dan membantu setiap kelompok agar } \\
\text { melakukan transisi secara efisien. }\end{array}$ \\
\hline $\begin{array}{l}\text { Fase 4 } \\
\text { Membimbing kelompok bekerja } \\
\text { dan belajar. }\end{array}$ & $\begin{array}{l}\text { Membimbing kelompok-kelompok belajar pada saat mereka } \\
\text { mengerjakan tugas mereka. }\end{array}$ \\
\hline $\begin{array}{l}\text { Fase 5 } \\
\text { Evaluasi. }\end{array}$ & $\begin{array}{l}\text { Mengevaluasi hasil belajar tentang materi yang telah diajarkan } \\
\text { atau masing-masing kelompok mempresentasikan hasil } \\
\text { kerjanya }\end{array}$ \\
\hline $\begin{array}{l}\text { Fase 6 } \\
\text { Memberikan penghargaan. }\end{array}$ & $\begin{array}{l}\text { Mencari cara-cara untuk menghargai baik upaya maupun hasil } \\
\text { belajar individu maupun kelompok. }\end{array}$ \\
\hline
\end{tabular}

Sumber: Trianto (2007)

\section{Pembelajaran Konvensional}

Pembelajaran konvensional adalah pembelajaran yang biasa dipakai guru dalam pembelajaran salah satunya adalah metode verbal, yakni metode ceramah. Metode ceramah merupakan suatu cara mengajar yang digunakan untuk menyampaikan keterangan dan informasi tentang suatu pokok persoalan serta masalah secara lisan. Dalam pembelajaran konvensional siswa dipandang sebagai yang belum mengetahui satu apapun dan hanya menerima bahanbahan yang diberikan guru. Guru adalah orang dewasa yang memiliki pengetahuan dan wewenang untuk menyampaikan pengetahuan itu kepada siswa.

\section{Metode Penelitian}

Penelitian ini akan dilaksanakan di SMA Swasta UISU Jalan Turi Medan. Penelitian dilakukan di SMA Swasta UISU Medan Semester I T.P 2010/2011. Populasi dalam penelitian ini adalah seluruh siswa kelas $\mathrm{X}$ SMA UISU MEDAN pada Tahun Ajaran
2010/2011 terdiri dari 4 kelas. Pengambilan sampel dilakukan secara acak (cluster random sampling) dimana setiap kelas memiliki kesempatan yang sama untuk menjadi sampel penelitian. Sampel yang diambil sebanyak dua kelas terdiri dari kelas kontrol dan kelas eksperimen. Penelitian ini termasuk jenis eksperimen, yaitu merupakan suatu kegiatan penelitian untuk melihat gejala yang muncul pada suatu kondisi tertentu jika diberikan perlakuan.

\section{Desain Penelitian}

Penelitian melibatkan dua kelas yang telah ditetapkan sebagai kelas eksperimen dan kelas kontrol. Untuk mengetahui hasil belajar Fisika siswa dilakukan dengan memberikan tes pada kedua kelas sebelum dan sesudah diberikan perlakuan. Desain penelitiannya dapat pada tabel berikut.

Tabel 2. Two Group Pretes-Postes Design

\begin{tabular}{|c|c|c|c|}
\hline Sample & Pretes & Perlakuan & Postes \\
\hline Kelas Eksperimen & $\mathrm{T}_{1}$ & $\mathrm{X}_{1}$ & $\mathrm{~T}_{2}$ \\
\hline Kelas Kontrol & $\mathrm{T}_{1}$ & $\mathrm{X}_{2}$ & $\mathrm{~T}_{2}$ \\
\hline
\end{tabular}


Keterangan:

$\mathrm{X}_{1}$ : Proses belajar-mengajar dengan menggunakan model kooperatif tipe STAD.

$\mathrm{X}_{2}$ : Proses belajar-mengajar sdengan menggunakan model pembelajaran konvensional.

$\mathrm{T}_{1}$ : Pretes diberikan kepada kelas eksperimen dan kelas kontrol sebelum perlakuan.

$\mathrm{T}_{2}$ : Postes diberikan kepada kelas eksperimen dan kelas kontrol setelah perlakuan.

Untuk melihat pengaruh dari model kooperatif tipe STAD pada kelas eksperimen, maka diberikan pretes kemudian diberikan perlakuan dan setelah itu diberikan postes.

Bila data penelitian berdistribusi normal dan homogen maka untuk menguji hipotesis menggunakan uji $\mathrm{t}$ dengan rumus (Sudjana, 2005), yaitu:

$\mathrm{t}=\frac{\bar{X}_{1}-\bar{X}_{2}}{S \sqrt{\frac{1}{n_{1}}+\frac{1}{n_{2}}}}$

Dimana $S$ adalah varians gabungan yang dihitung dengan rumus:

$$
S^{2}=\frac{\left(n_{1}-1\right) S_{1}{ }^{2}+\left(n_{2}-1\right) S_{2}{ }^{2}}{n_{1}+n_{2}-2}
$$

Kriteria pengujian adalah: terima $\mathrm{H}_{\mathrm{O}}$ jika $-t_{1-\frac{1}{2}} \alpha<t<t_{1-1 / 2} \alpha$ dimana $t_{1-1 / 2} \alpha$ didapat dari daftar distribusi t dengan $\mathrm{dk}=\mathrm{n}_{1}+\mathrm{n}_{2}-2$ dan $\alpha=0,10$. Untuk harga $\mathrm{t}$ lainnya $\mathrm{H}_{\mathrm{O}}$ ditolak. Jika analisis data menunjukkan bahwa $-t_{1-\frac{1}{2}} \alpha<t<t_{1-\frac{1}{2}} \alpha$ maka hipotesis $\mathrm{H}_{0}$ diterima, berarti kemampuan awal siswa pada kelas eksperimen sama dengan kemampuan awal siswa pada kelas eksperimen. Untuk hal lain $\mathrm{H}_{0}$ ditolak dan terima $\mathrm{H}_{\mathrm{a}}$

\section{Hasil Penelitian dan Pembahasan}

Hasil penelitian yang dilakukan untuk mengetahui hasil belajar siswa sebelum kedua sampel diterapkan perlakuan yang berbeda, yaitu kelas eksperimen diberi perlakuan dengan menggunakan model pembelajaran Kooperatif Tipe STAD dan kelas kontrol diberi perlakuan dengan menggunakan model pembelajaran konvensional, diperoleh nilai rata-rata pretes kelas eksperimen 41,31 dan standar deviasinya 9,91 sedangkan untuk kelas kontrol nilai ratarata pretes 40,78 dan standar deviasinya 10,16 dengan nilai tertinggi 55 dan terendah 20.

Setelah kedua sampel diterapkan perlakuan yang berbeda diperoleh nilai rata-rata postes kelas eksperimen 69,07 dengan standar deviasinya 10,19 dengan nilai tertinggi 85 dan terendah 50 sedangkan untuk kelas kontrol ratarata postes 61,84 dan standar deviasinya 9,89 dengan nilai tertinggi 80 dan terendah 45 .

Sebelum dilakukan uji hipotesis terlebih dahulu dilakukan uji prasyarat data dengan uji normalitas Liliefors. Berdasarkan hasil perhitungan data pretes kelas eksperimen diperoleh $\mathrm{L}_{\text {hitung }}<\mathrm{L}_{\text {tabel }}(0,1097<0,1404)$ dan data pretes kelas kontrol diperoleh $\mathrm{L}_{\text {hitung }}<\mathrm{L}_{\text {tabel }}(0,0922<$ 0,1404) sehingga dapat disimpulkan bahwa data dari kedua kelas berdistribusi normal. Kemudian pengujian homogenitas dilakukan untuk mengetahui apakah kelas sampel berasal dari populasi yang homogen atau tidak, artinya apakah sampel yang dipakai dalam penelitian ini dapat mewakili seluruh populasi yang ada. Hasil perhitungan diperoleh nilai $\mathrm{F}_{\text {hitung }}<\mathrm{F}_{\text {tabel }}$ yang berarti bahwa sampel yang digunakan dalam penelitian ini dinyatakan homogen atau dapat mewakili seluruh populasi yang ada.

Selanjutnya dilakukan penghujian hipotesis untuk data pretes menggunakan uji t. Hasil perhitungan diperoleh $\mathrm{t}_{\text {hitung }}=0,230<\mathrm{t}_{\text {tabel }}=$ 1,995. Ini berarti siswa dari kedua kelompok sampel memiliki kemampuan yang sama. Kemudian untuk melihat adanya pengaruh perlakuan terhadap hasil belajar siswa, maka dilakukan uji $\mathrm{t}$ satu pihak, dan diperoleh $\mathrm{t}_{\text {hitung }}=$ $3,138>\mathrm{t}_{\text {tabel }}=1,667$. Hal ini menunjukkan bahwa ada pengaruh model pembelajaran kooperatif tipe STAD terhadap hasil belajar Fisika siswa pada materi pokok gerak lurus di kelas X SMA Swasta UISU T.P.2010/2011. Masing-masing data pretes dari kedua kelompok sampel diperoleh $\mathrm{F}_{\text {hitung }}<\mathrm{F}_{\text {tabel }}$ dan postes dari kedua kelompok sampel diperoleh $\mathrm{F}_{\text {hitung }}>\mathrm{F}_{\text {tabel }}$. Seperti tertera pada tabel di bawah ini. 
Lubis, A.: Pengaruh Model Pembelajaran Kooperatif Tipe STAD Terhadap Hasil Belajar Fisika Siswa Pada Materi Pokok Gerak Lurus di Kelas X SMA Swasta UISU Medan.

\section{Pembahasan}

Temuan hasil penelitian ini menggambarkan adanya pengaruh yang signifikan antara model pembelajaran kooperatif tipe STAD terhadap hasil belajar Fisika siswa pada materi pokok gerak lurus di kelas X SMA Swasta UISU T.P.2010/2011. Pada awal penelitian ini terlebih dahulu siswa diberikan pretes untuk mengetahui kemampuan awal siswa, kemudian diberikan perlakuan untuk masing-masing sampel dan setelah itu diadakan postes untuk mengetahui kemampuan akhir siswa.

Adapun nilai rata-rata pretes untuk kelas eksperimen adalah 41,31 dan standar deviasi 9,91 sedangkan untuk kelas kontrol 40,78 dan standar deviasi 10,16 dengan nilai tertinggi 55 dan nilai terendah 20. Begitu juga dengan ratarata nilai hasil belajar siswa (postes) pada kelas yang menggunakan model pembelajaran kooperatif tipe STAD adalah 69,07 dengan nilai tertinggi 85 dan nilai terendah 50 serta nilai standar deviasianya adalah 10,19 , sedangkan pada kelas yang menggunakan pembelajaran konvensional diperoleh rata-rata nilai hasil belajar siswa dalah 61,84 dengan nilai tertinggi 80 dan terendah 45 serta dengan nilai standar deviasi adalah 9,86.

Berdasarkan hasil pengujian hipotesis pada menggunakan uji $\mathrm{t}$ diperoleh $\mathrm{t}_{\text {hitung }}=0,230$ $<\mathrm{t}_{\text {tabel }}=1,995$, dan dinyatakan siswa dari kedua kelompok sampel memiliki kemampuan awal yang sama. Untuk melihat adanya pengaruh setelah dilakukan perlakuan maka digunakan uji $\mathrm{t}$ satu pihak dan diperoleh $\mathrm{t}_{\text {hitung }}=3,138>$ $\mathrm{t}_{\text {tabel }}=1,667$, maka dapat disimpulkan bahwa ada pengaruh yang signifikan antara model pembelajaran kooperatif tipe STAD terhadap hasil belajar Fisika siswa pada materi pokok gerak lurus di kelas X SMA Swasta UISU T.P.2010/2011.

\section{Simpulan}

Berdasarkan hasil penelitian data dan uji statistik serta pembahasan maka dapat disimpul-
Jurnal Pendidikan Fisika

p-ISSN 2252-732X

e-ISSN2301-7651

kan bahwa (1) Hasil belajar Fisika siswa pada materi pokok gerak lurus setelah menerapkan model pembelajaran kooperatif tipe STAD memilki nilai rata-rata pretes 41,31 dan nilai rata-rata postes adalah 69,07. (2) Hasil belajar Fisika siswa dengan mengunakan model pembelajaran konvensional memiliki nilai rata-rata pretes 40,78 dan nilai rata-rata postes 61,84 . (3) Ada perbedaan pengaruh yang signifikan pada pengunaan model pembelajaran kooperatif tipe STAD terhadap hasil belajar Fisika siswa pada materi pokok gerak lurus di kelas X SMA Swasta UISU T.P.2010/2011.

\section{Daftar Pustaka}

Gelora. 2008. Pengaruh Model Pembelajaran Kooperatif Tipe STAD Terhadap Hasil Belajar Siswa Pada Materi Pokok Besaran dan Satuam di SMA SWASTA Santo Thomas 3 T.P.2008/2009. Medan: Unimed

Ibrahim, M. 2000. Pembelajaran Kooperatif. Surabaya: UNS.

Joyce, B. dan Weil, M. 1980. Models of Teaching. New Jersey: Prentice-Hall, Englewood Clipffs.

Lie, A. 2004. Cooperative Learning. Jakarta: Gramedia.

Sanjaya, W. 2008. Strategi Pembelajaran. Jakarta: Prenada Media.

Sardiman, A.M. 2003. Interaksi dan Motivasi Belajar mengajar. Jakarta: PT. Raja Grafindo Persada.

Slameto. 2003. Belajar dan Faktor-Faktor yang Mempengaruhinya. Jakarta: Penerbit Rineka Cipta.

Slavin,R.E. 2008. Cooperative Learning Teori, Riset dan Praktik. Bandung: Nusa Media

Sudjana. 2005. Metoda Statistika. Bandung: Tarsito.

Trianto. 2007. Model-model Pembelajaran Inovatif Berorientasi Konstruktivistik. Jakarta: Prestasi Pustaka Publisher. 